Historic, Archive Document

Do not assume content reflects current scientific knowledge, policies, or practices. 



\section{EVERGREENS FOR THE \\ HOME LANDSCAPE IN DECEMBER}

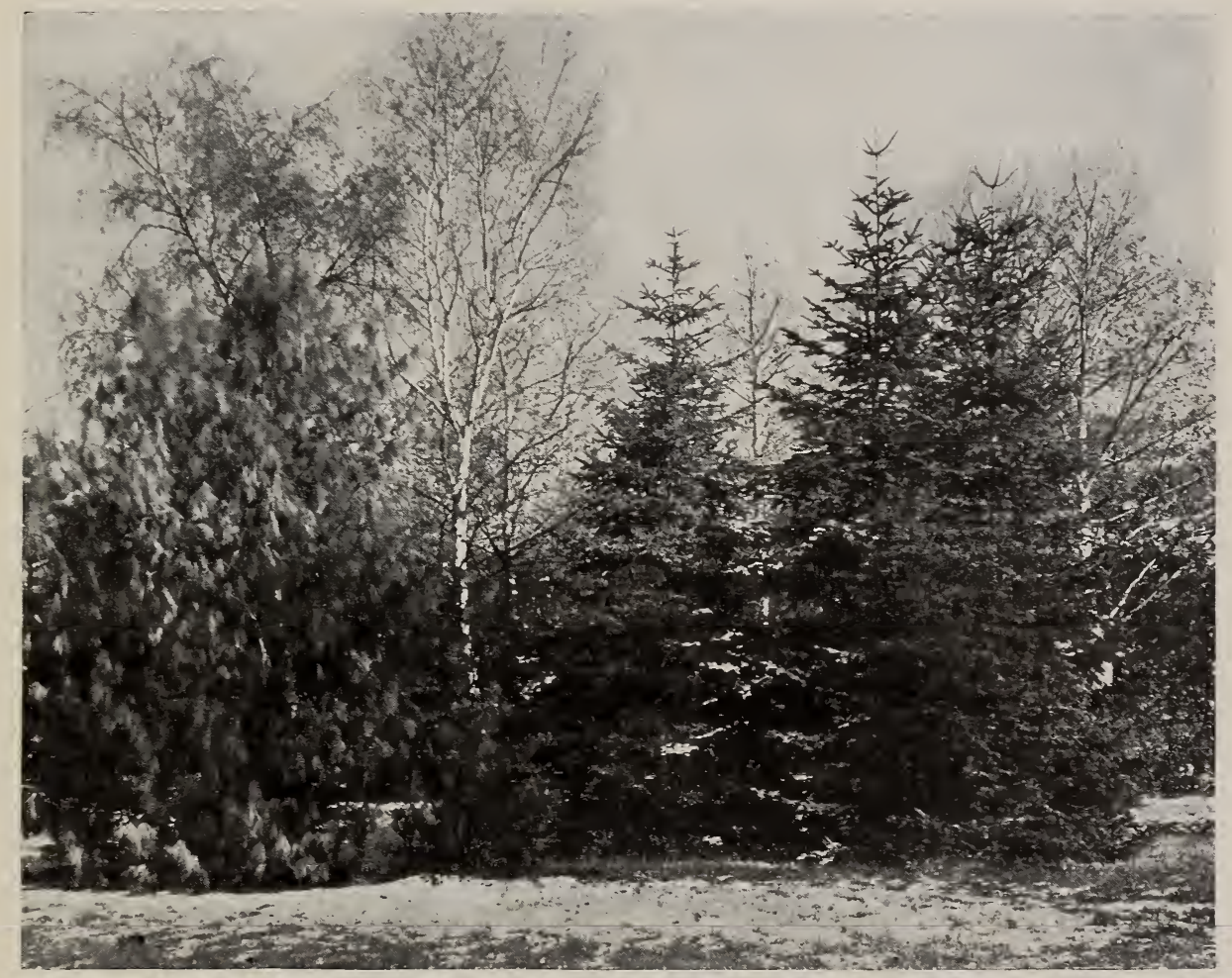

PINE, FIR AND WHITE BIRCH : A SUGGESTION FOR A CHRISTMAS GIFT

\section{HICKS NURSERIES}

I. HICKS \& SON

WESTBURY, LONG ISLAND, N.Y. 

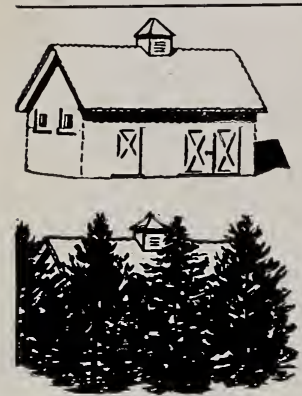

Is this your requirement? We can quickly make the transformation. Send us the height, width and length, and we will plan as economically as possible. Why not at once?

\section{December and all Winter Plant- ing Will be Welcome}

IF your place has the usual shrubs and trees, bare and uninteresting at this season.

IF you need to screen unattractive surroundings, garage, stable, poultry house, laundry yard, or street.

IF you admire evergreens and want them for their own beauty in Summer, late Fall, Winter and early Spring.

IF you need windbreaks to your house, garden, out door room, or play ground.

IF you enjoy hunting big Cedars, Pines, Oaks, Maples, Dogwoods, Laurel, etc., and making your place look like an old place right away.

IF you have evergreens, deciduous trees or shrubs to move to other parts of your grounds or give away or sell.

IF you wish to prevent winter unemployment. We can provide apparatus and men to co-operate with your men or we can attend to the entire operations. IF you wish to take advantage of present reduced prices.

\section{Don't put off till April what can be done in December. Talk it over with your landscape architect and gardener.}

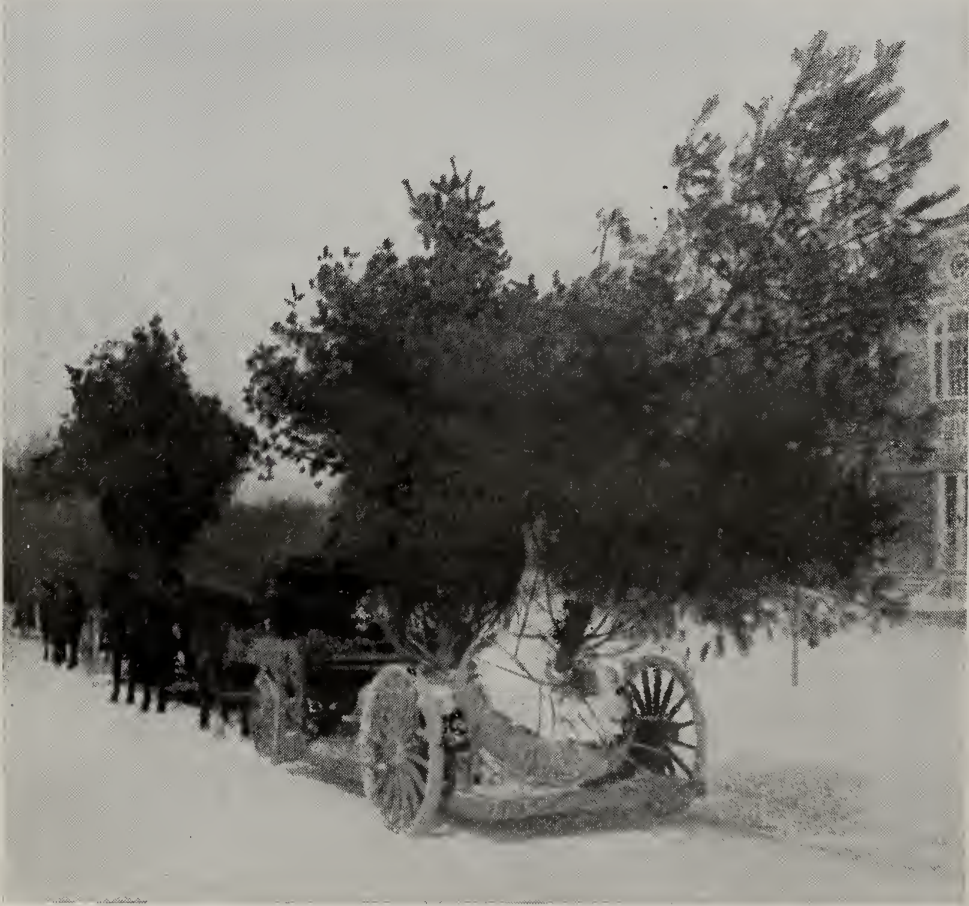

White Pines $14 \mathrm{ft}$. We have 200 such trees. They are 8 to $10 \mathrm{ft}$. broad. They can be crated as illustrated on page 6 , shipped a thousand miles and safely planted by your men. We have shipped 125 carloads of big evergreens, 8 to $30 \mathrm{ft}$. high; satisfaction guaranteed.

\section{The Proof}

Hicks Nurseries employed Ioo men last winter, except I 4 days. Half were digging trees, despite the fact that "The average temperature for the state was the lowest for any February since the establishment of the Climatological Service." It has been our practice for 10 years to keep almost a full crew all winter. Our winter sales for the past four years were $\$ \mathbf{I} 6,000.00$.

In December small trees and shrubs are dug as in October or April.

The ground frozen at night softens during the day, or by a moist south wind or rain.

In January the ground freezes six inches but is easily worked, if previously mulched as illustrated on page 5 .

On the mainland the frost is deeper and more continuous, but it is easy to dig through with pick or cold chisel.

If it costs a few cents additional to plant we will bear that to keep our staff all winter. 


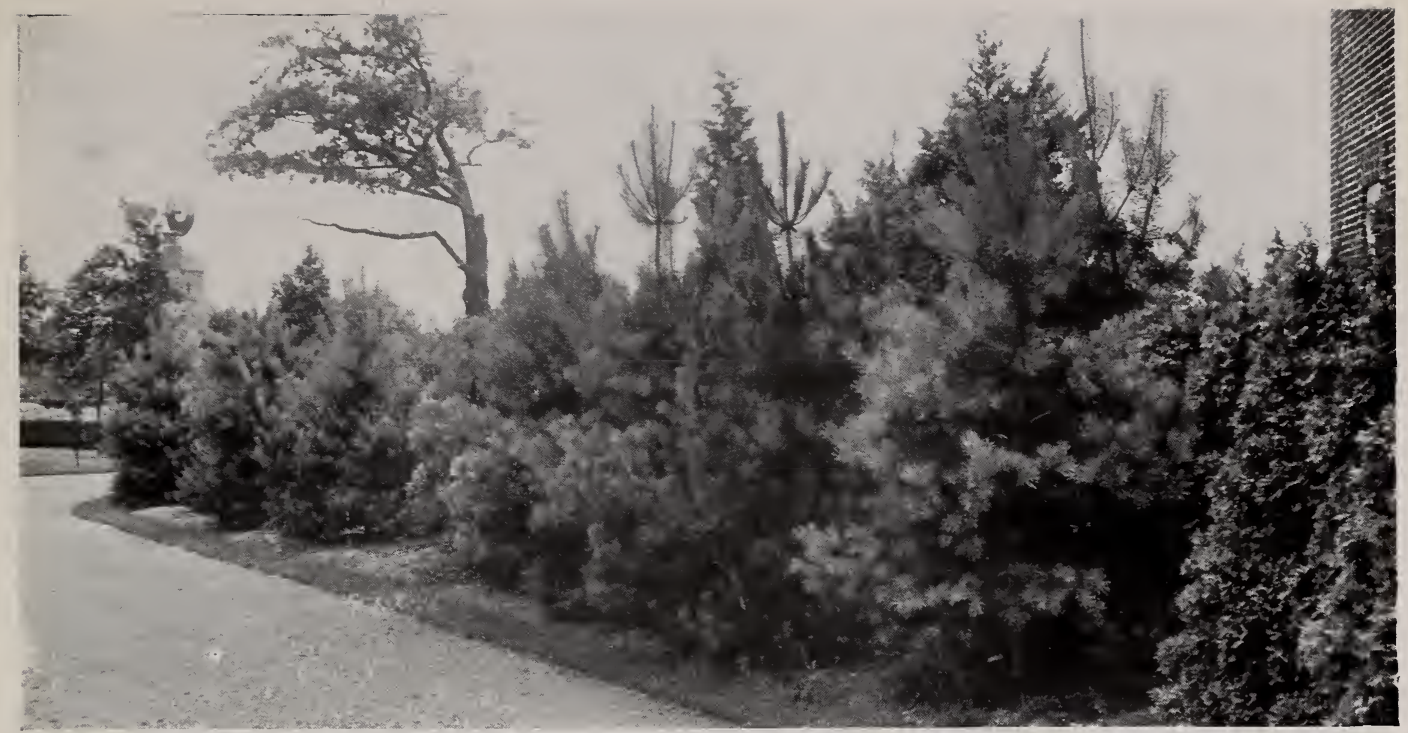

Pines grouped along entrance drive as a screen to the service court. We can reproduce immediately the planting illustrated. Such a screen 7 to $9 \mathrm{ft}$. high costs $\$ 2.00 \mathrm{per} \mathrm{ft}$. of length. Is not such a requirement and decoration worth your decision now? We will send a representative, if you say so, to discuss the cletails. You can order by phone or mail and receive the trees promptly.

\section{BUSINESS TERMS}

Prices in this catalogue do not include delivery or packing, which are charged according to cost. 5,50 and 500 plants at 10,100 and 1000 rates, respectively. Terms net cash.

\section{GUARANTEE}

We guarantee every tree from the nursery. New trees free for any that die or grow unsatisfactorily.

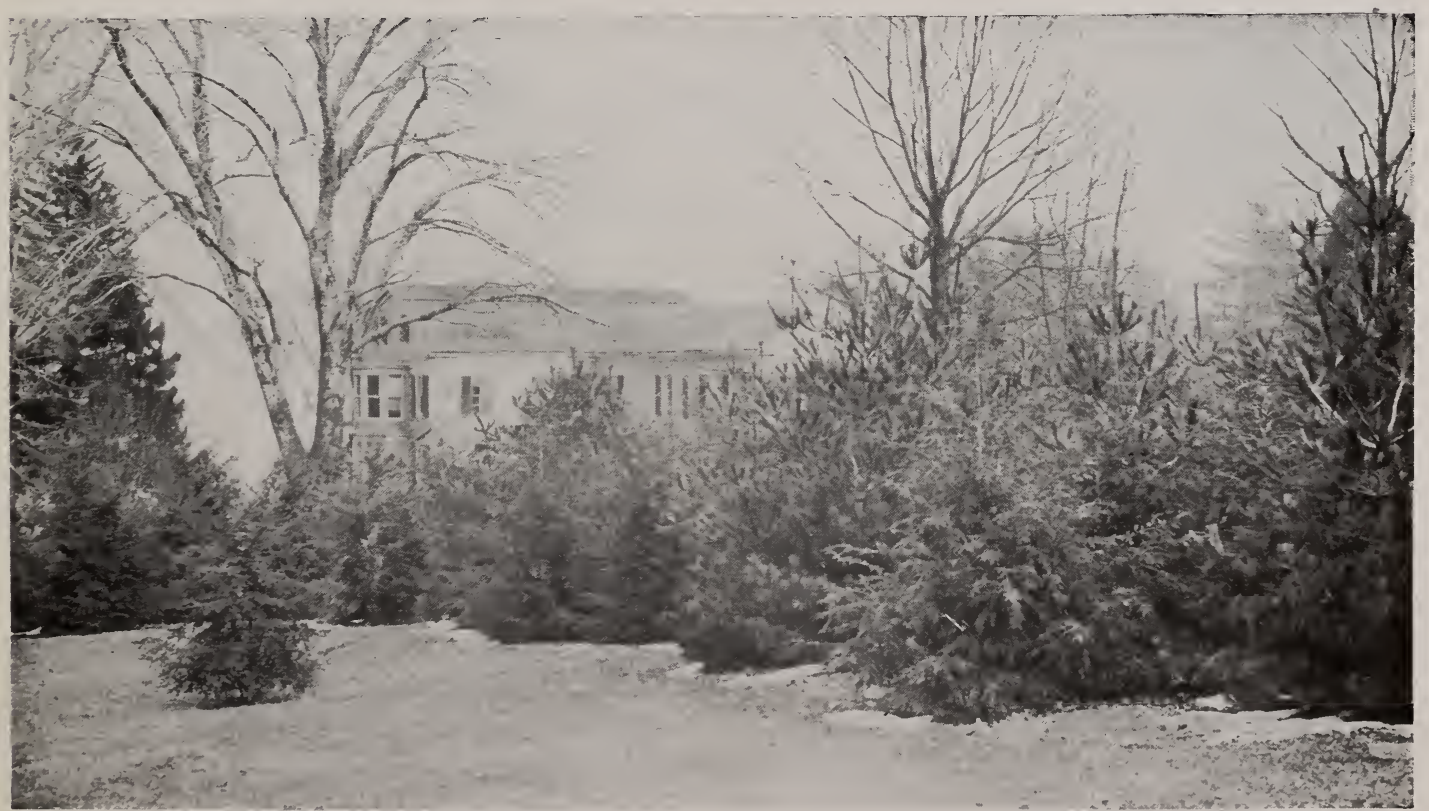

Boundary belt of White Fine and Hemlock. Subdues the north wind; sifts the dust and muffles the noise from the highway; and blocks out adjacent houses in a way that is mutually satisfactory.

You may be interested in one or all of these functions. $\$ 50.00$ will purchase trees 6 to $8 \mathrm{ft}$. high for a belt $50 \mathrm{ft}$. long. Our apparatus was used to thin out this plantation before it crowded.

Have you evergreens that should be moved, before they crowd, to other parts of your grounds, or to a neighbor's? 


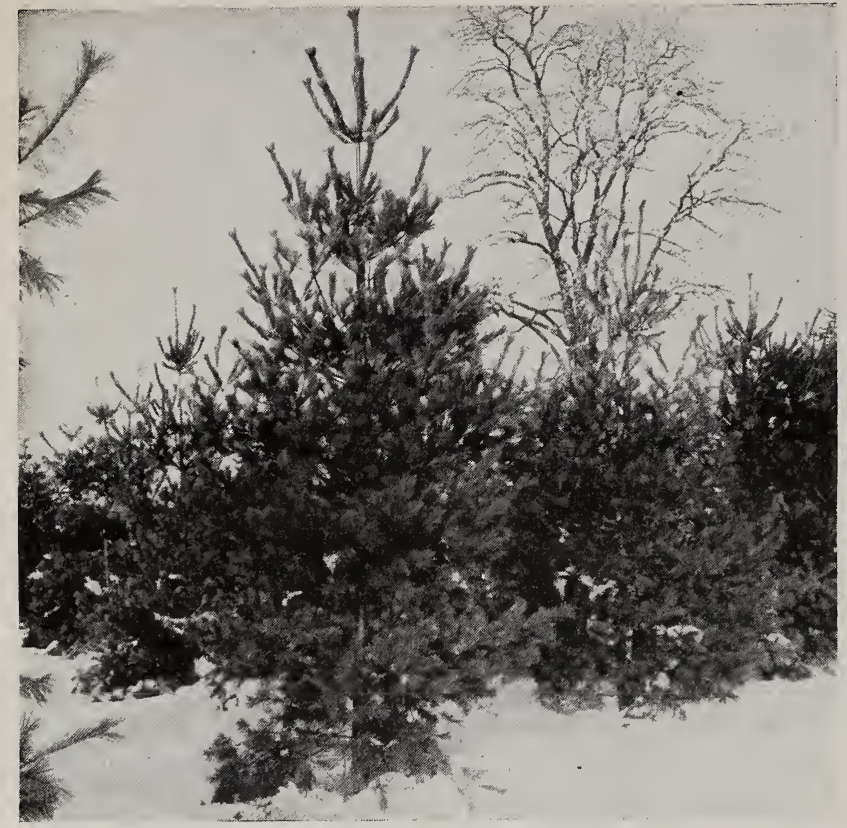

White Pine 10 to $14 \mathrm{Ft}$. This block was transplanted in February 1912. Out of 150 trees only I died. They will plant just as successfully on your grounds now. They are grown economically in large quantities, and are, therefore, offered at lower price than formerly. They are growing in squares $12 \mathrm{ft}$. apart. Their production has required time, skill, and money. Their value to you consists in the 8 years' waiting you are saved; their broad, dense tops and vigorous growth the first year.

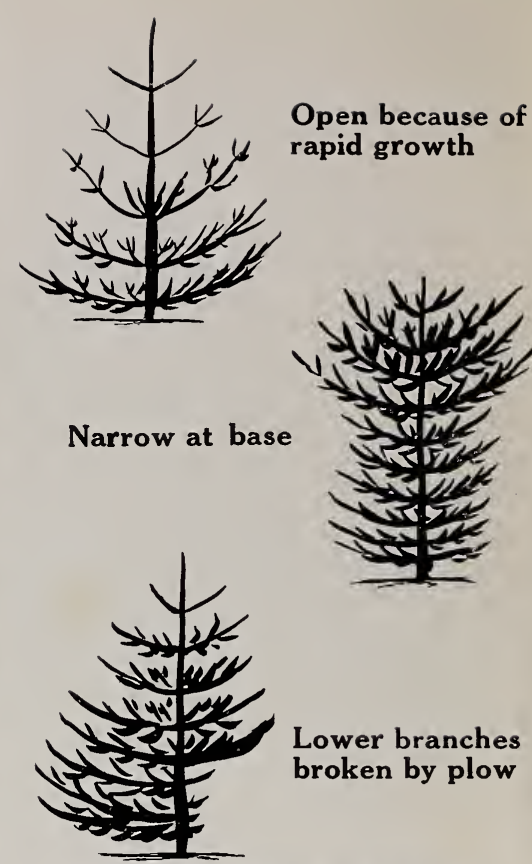

Irregular trees at low prices

Sure to grow but not the conventional A shapa tree.

Come and see them and be convinced of their value. The landscape unit is a colony or group of trees. These are ideal material.

\section{White Pine}

\begin{tabular}{|c|c|c|c|}
\hline \multicolumn{3}{|c|}{ Reduced Prices } & \multirow[b]{2}{*}{$\begin{array}{l}\text { Low prices on irregular } \\
\text { trees as sketched above } \\
\text { Each }\end{array}$} \\
\hline Each & Per Io & 100 & \\
\hline$\$ 1.00$ & $\$ 7.50$ & $\$ 65.00$ & $\$ \quad .50$ \\
\hline I. 75 & 15.00 & 140.00 & 1.00 \\
\hline 2.75 & 25.00 & 200.00 & I. 75 \\
\hline 4.00 & 35.00 & & 2.50 \\
\hline 6.00 & 55.00 & & 4.00 \\
\hline 10.00 & 85.00 & & 6.00 \\
\hline 12.00 & 105.00 & & 5.00 to 9.00 \\
\hline I6.00 & I 40.00 & & 7.00 to $12 . \mathrm{co}$ \\
\hline 25.00 & 210.00 & & I2.00 to I 6.00 \\
\hline 35.00 & 320.00 & & I 5.00 to 20.00 \\
\hline
\end{tabular}

\section{Worth While Work for Your Men This Winter}

Make humus of leaves, manure, weeds, thatch, salt hay, seaweed, eel grass, sawdust. Dig it in or pile it to decay. Some plants need humus with lime, and some require acid soil. Get "Agricultural Utilization of Acid Lands by means of Acid Tolerant Crops," at Government Printing Office, Washington, D. C. Five cents.

Dig trenches for irrigation pipes. Water and humus are the two elements needed for full production from your soil. Send for irrigation catalogs of SKINNER IrRIGAtion Co. Troy, Ohio; International Steam Pump Co., N. Y.; J. P. Campbell, Jacksonvillle, Fla.

Mulch ground with manure, leaves, weeds, thatch, or salt hay to permit digging trees, digging trenches, grading, carting soil, screening gravel for roads or concrete.

Cut dead Chestnut trees and remove stumps. Spray, prune, and cut out borers. 


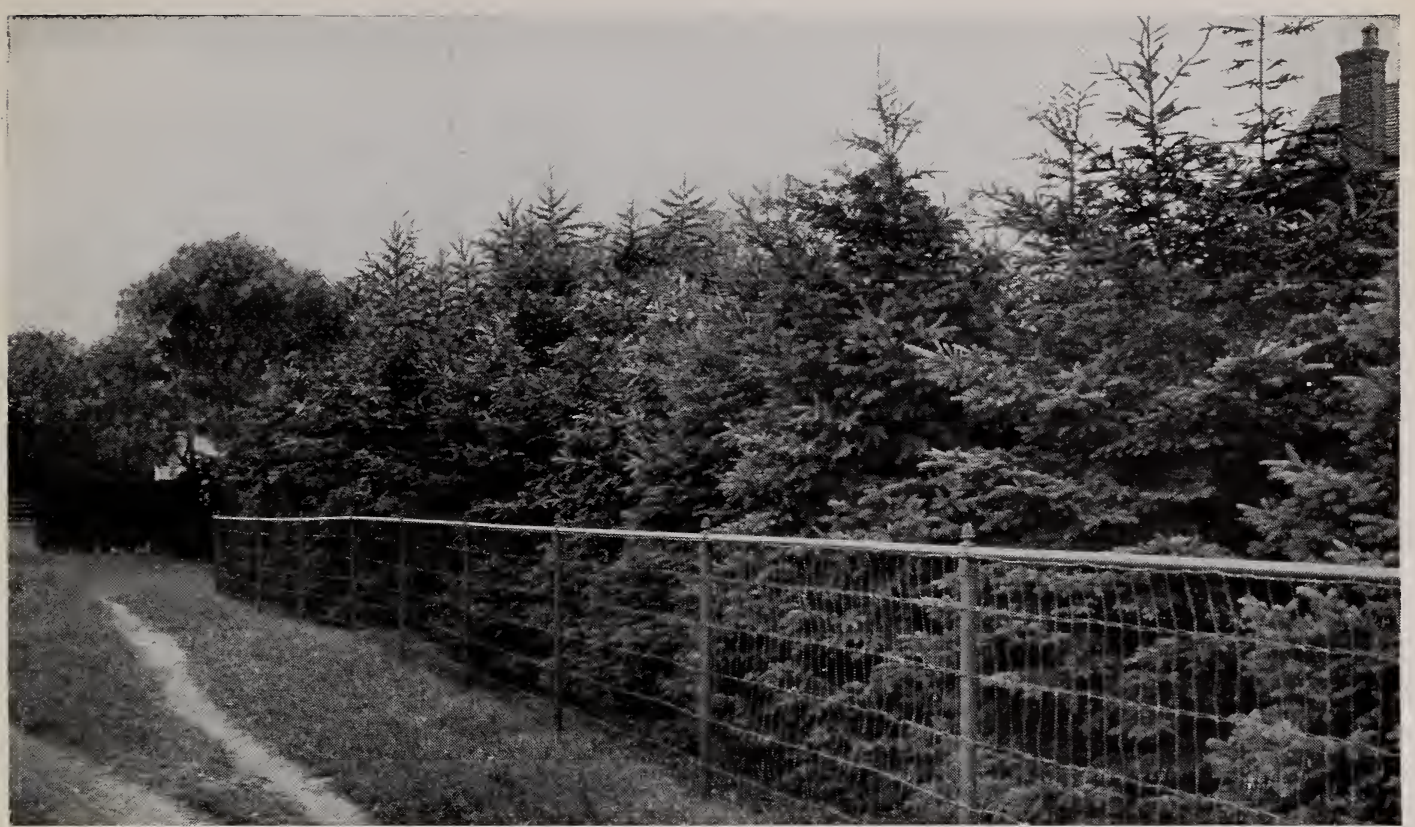

White Spruce Hfdge. Does a hedge represent your need? Have you a flower or vegetable garden to enclose? Do you wish to curtain off the highway, or build a partition around the service or forecourt? We can supply 5 foot White Spruce that will gain a foot each year. You can plant such a hedge now at \$I.00 per linear foot. White Spruce is perfectly hardy, dense cheerful blue green. Send for "Evergreens for August-September Planting describing fully what White Spruce will do for you. We guarantee the trees.

\section{White Spruce}

We have reduced the price because we want to sell 5,000 this winter.

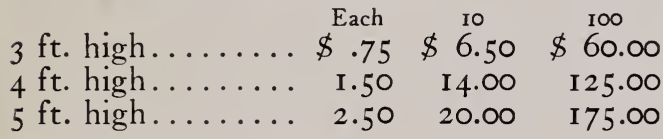

\section{Douglas Spruce}

Graceful, feathery trees of rapid growth. Cheerful blue-green foliage.

\begin{tabular}{|c|c|c|}
\hline $3 \mathrm{ft}$. & $\$ 2.00$ & $\$ 17.50$ \\
\hline $4 \mathrm{ft} ., 3 \mathrm{ft} . \mathrm{spr} . \ldots$ & 3.00 & 25.00 \\
\hline ft., 3 ft. spr. . . . & 5.00 & 40.00 \\
\hline ft., $3-4$ ft. spr... & 8.00 & 70.00 \\
\hline ft., $3-4$ ft. sp $\ldots$ & 9.00 & 80.00 \\
\hline ft., $4-5$ ft. spr... & 16.00 & 150.00 \\
\hline t., $4-5 \mathrm{ft}$. spr.... & 20.00 & 175.00 \\
\hline ft., $4-6 \pm t$. spr. & 30.00 & 250.00 \\
\hline
\end{tabular}

\begin{tabular}{|c|c|}
\hline . & $\$ 3.00$ \\
\hline h, $2 \frac{1}{2}-$ & 5.00 \\
\hline or. & 8.00 \\
\hline r. & I I 1.00 \\
\hline & \\
\hline
\end{tabular}

\section{Colorado Blue Spruce}

$3 \mathrm{ft}$. high, 9 yrs.... \$3.00 \$25.00 \$200.00 4 ft.high, 3 ft.spr.,9 yrs. $4.00 \quad 35.00 \quad 300.00$ $5 \mathrm{ft}$. high, 3-4 ft. spr. $7.00 \quad 65.00$

\section{Nordmann's Fir}

Pyramid of dark shining green.

$4 \mathrm{ft}$. high, $3-4 \mathrm{ft} . \mathrm{spr} \ldots \ldots \ldots \$ 4.50 \quad \$ 37.50$ $5 \mathrm{ft}$. high, $4-5 \mathrm{ft}$. spr...... $6.00 \quad 55.00$ $6 \mathrm{ft}$. high, $4-5 \mathrm{ft}$. spr...... $9.00 \quad 80.00$ $7 \mathrm{ft}$. high, $5-7 \mathrm{ft}$. spr....... I 2.00 I00.00 $8 \mathrm{ft}$. high, $5-7 \mathrm{ft}$. spr...... $20.00 \quad$ I 80.00

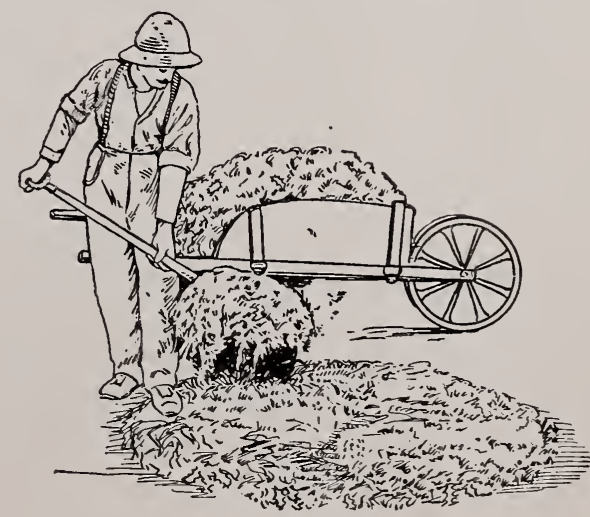

Mulching like this in December will prepare the ground for digging and planting any time in the winter. Hold the mulch, with soil, brush, boards or thatch.

Irregular trees of these and other varieties at 20 to 60 per cent. reduction. They have good roots and big balls of earth. Call and select or send for list. They are similar to those sketched on page 4. They can be returned at our expense if unsatisfactory. 


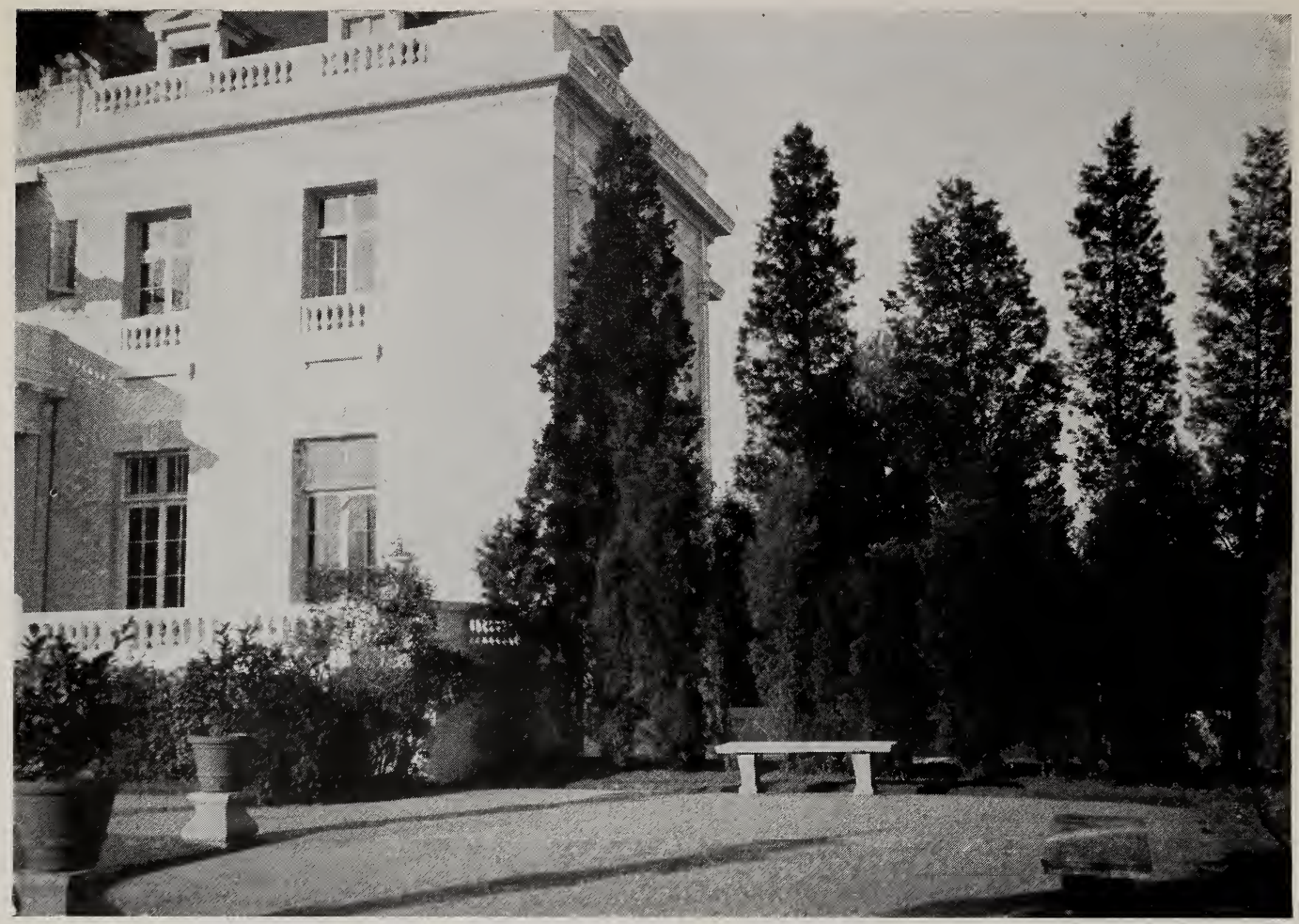

Here are wild Cedars we brought in during the Winter. In such an enclosure, shut in on four sides but open to the sun and sky one can retire for fresh air, the children can play or the baby can sleep. It is warm and calm, for the wind is checked and the warmth of the sunbeams is intensified. There is inspiration in the sky line with the points of varying height, striving for supremacy. There is interest in the shadows. We can build such an enclosure right now with wild Cedars from your vicinity or Cedars that have been growing in the nursery one to seven years. What do you say?

\section{Red Cedar}

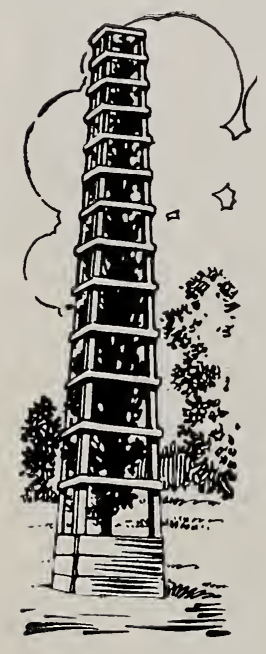

A single $\mathrm{Ced}$ a $\mathrm{r}$ or ther everg reen rwenty feet high can be shipped as readily as a carload.

We have several thousand cedars in the nursery to select from.

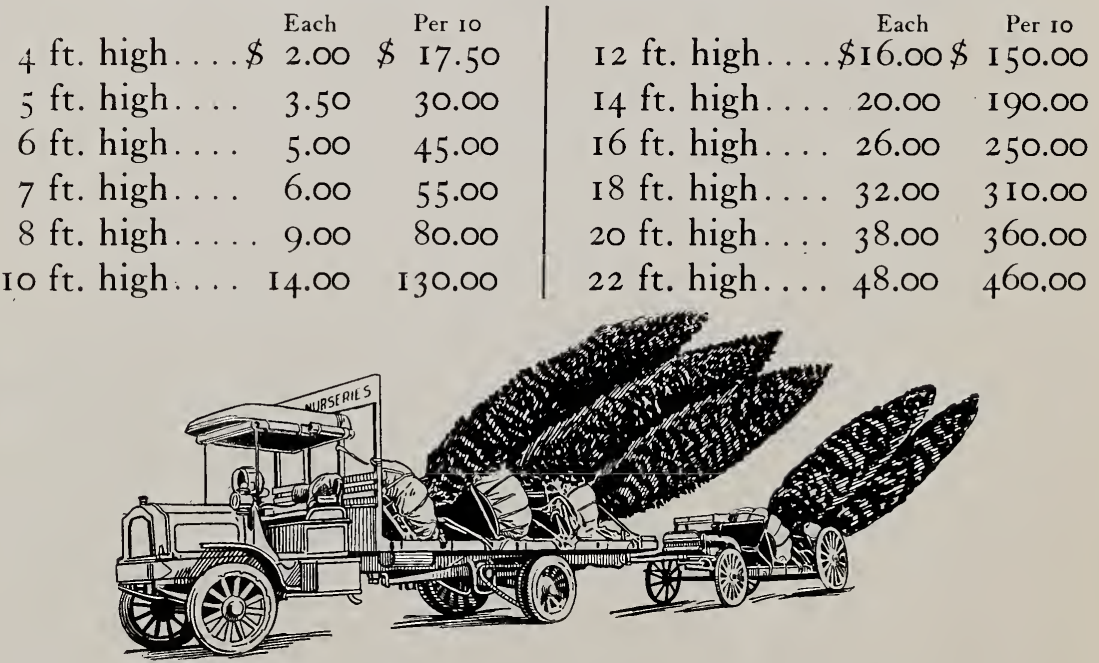

We can deliver within a radius of 50 miles, or bring in wild trees.

\section{Other Things You Can Do This Winter}

Plant large shade trees as Maples, Lindens, Oaks, 20-40 ft. high. Call at the nursery and select them, or send for photos of numbered specimens in foliage. To keep out the frost, we will arrange details of mulching the trees in the nursery and the place to be planted. There is always mild weather for moving them.

Shrubs and hedges can frequently be planted in mild weather in winter. 


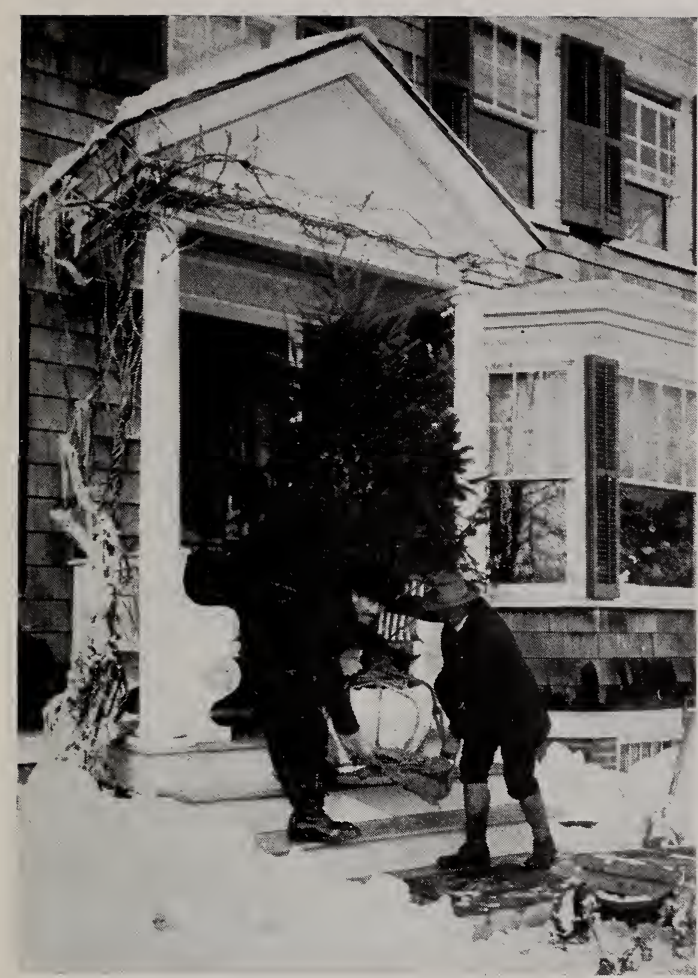

Bringing in the Christmas tree. Set in a box or tub without removing the burlap and water like a potted plant.

\section{Christmas Gifts}

Can you imagine a more beautiful, permanent, acceptable Christmas gift than a group of evergreens? It can be an ornamental or serviceable group or both in one.

\section{$\$ 25.00$ Group}

3 White Pines $6 \mathrm{ft} ., 2$ Colorado Spruce $4 \mathrm{ft}$., 8 White Spruce $3 \mathrm{ft}$.

\section{$\$ 50.00$ Group}

2 White Pines $7 \mathrm{ft}$., 3 White Pines 6 ft., 4 Colorado Blue Spruce $3 \mathrm{ft} ., 2$ Nordmann's Fir $4 \mathrm{ft}$., Io White Spruce $3 \mathrm{ft}$., for a group $50 \mathrm{ft}$. $\mathrm{x} 20 \mathrm{ft}$.

\section{$\$ 100.00$ Group}

2 White Pines $\mathrm{I} 2 \mathrm{ft} ., 2$ White Pines Io $\mathrm{ft} ., 2$ White Pines $8 \mathrm{ft}$. If irregular trees $\$ 60.00$. See page 4 .

\section{Live \\ Christmas Trees}

Did you buy a live Christmas tree last year and plant it after the holidays? We recommend White Spruce, Douglas Spruce, Colorado Spruce, and Nordmann's Fir. See page 5 for prices. Place your order now and we will have the trees ready when you call to take in your car, or we can deliver if you prefer. Customers from a distance should allow ample time for transportation. Trees up to $5 \mathrm{ft}$. for shipment will be securely crated at $\$ .50$ extra. See page 5 for mulching.

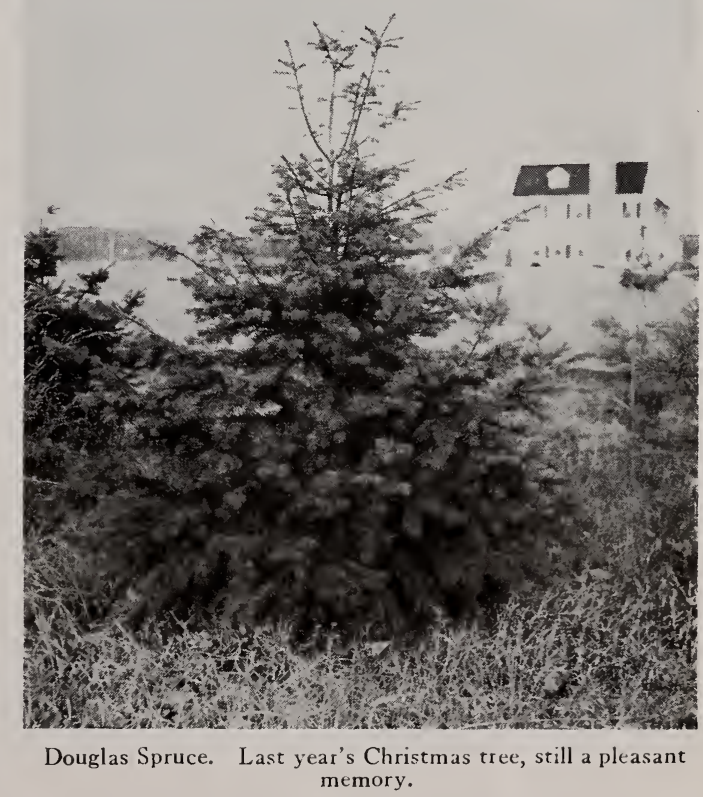

\section{Other Ways Hicks Nursery May Help You}

Fruits, Flowers, Rhododendrons, Flowering Shrubs, Berry-bearing Shrubs and evergreen groups to attract the birds. Trees and shrubs for dry and sandy ground. Large tree moving, deciduous trees with spread of roots and tops of $30 \mathrm{ft}$. Evergreens up to $40 \mathrm{ft}$ high. Send for literature. It tells you what to do regardless of whether you buy trees or not.

What is your location and soil? Let us consider it with you now, instead of next April. 


\section{December Opportunities}

Plant evergreen screens, wind breaks, hedges, and groups for beautiful all the year, landscapes.

Select Christmas presents, a single tree or a group.

Plan winter work for your men collecting wild cedars and shrubs, or moving evergreens and deciduous trees on your place, with the co-operation of our apparatus and men. For humus and irrigation see page 4 .

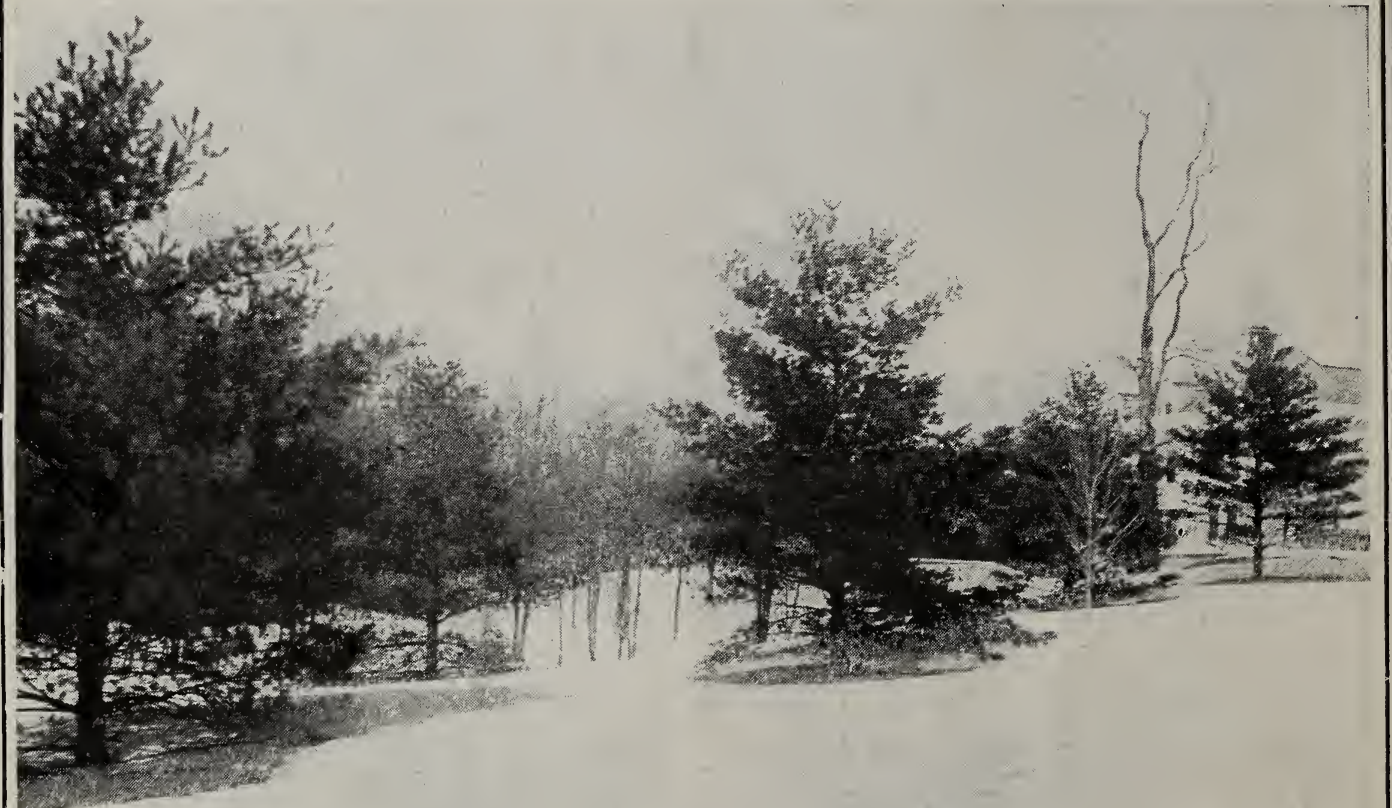

WHITE PINE PLANTED IN WINTER FROM HICKS NURSERIES

PHOTOGRAPHED 1912

HICKS NURSERIES

WESTBURY

LONG ISLAND 